https://doi.org/10.15407/ufm.20.02.285

O.M. IVASISHIN ', P.E. MARKOVSKY ', D.G. SAVVAKIN ',

O.O. STASIUK ', V.A. GOLUB ${ }^{2}$, V.I. MIRNENKO ${ }^{2}$, S.H. SEDOV ${ }^{2}$,

V.A. KURBAN ${ }^{2}$, and S.L. ANTONYUK ${ }^{3}$

1 G.V. Kurdyumov Institute for Metal Physics, N.A.S. of Ukraine,

36 Academician Vernadsky Blvd., UA-03142 Kyiv, Ukraine

${ }^{2}$ Ivan Cherniakhovsky National Defence University of Ukraine,

28 Povitroflotsky Ave., UA-02093 Kyiv, Ukraine

${ }^{3}$ SC 'ANTONOV',

1 Tupolev Str., UA-03062 Kyiv, Ukraine

\title{
MICROSTRUCTURE AND PROPERTIES OF TITANIUM-BASED MATERIALS PROMISING FOR ANTIBALLISTIC PROTECTION
}

\begin{abstract}
Titanium-based materials, which combine high strength and hardness of surface layer along with sufficient ductile characteristics of the matrix metal, are very promising for various applications, particularly, as armoured components in military-industrial complex. Above-mentioned combination of properties can be achieved by means of the creation of multilayer structures, which consist of layers possessing different physical and mechanical properties. In the present study, microstructure peculiarities, mechanical and antiballistic protection properties of the layered Tibased materials are investigated. Two different ways were used for fabrication of such the layered structures. The first one is a conventional metallurgical (ingotwrought) method followed by the surface rapid heat treatment of the $\mathrm{Ti}-6 \mathrm{Al}-4 \mathrm{~V}$ and T110 alloys for fabrication of graded structures with different mechanical properties over the material depth. The second one is an elemental powder metallurgy method for fabrication of the structures combining layers of the Ti-6Al-4V alloy and composites based on it and hardened with $\mathrm{TiC}$ or $\mathrm{TiB}$ particles. Ballistic tests of the obtained materials are carried out for different types of projectiles with different kinetic energy and hardness of the core; features of the penetration of the hitting elements are performed depending on the material structural state. It is proved that materials with graded and layered structures demonstrate undeniable advantages in the antiballistic protection characteristics as compared with homogeneous alloys of the same thickness.
\end{abstract}

Keywords: titanium alloys, layered and graded microstructures, mechanical characteristics, ballistic tests.

(c) O.M. IVASISHIN, P.E. MARKOVSKY, D.G. SAVVAKIN, O.O. STASIUK, V.A. GOLUB, V.I. MIRNENKO, S.H. SEDOV, V.A. KURBAN, S.L. ANTONYUK, 2019 


\section{Introduction}

High levels of strength and corrosion resistance at low specific weight of titanium-based materials ensure their widespread use in aviation, chemical industry, medicine, etc. [1,2]. Titanium alloys are also successfully used for military applications [3-6], in particular for the manufacture of armoured elements of battlefield vehicles and military equipment, as well as for personnel protection. Replacement of traditional steel armour elements on titanium ones having comparable strength characteristics of these materials can significantly reduce the weight of structures and increase the period of their operation.

The general modern trends in the creation of protective armoured elements consist in simultaneous achieving a high strength and hardness with sufficient characteristics of ductility of the material. A promising way to achieve this is to create multilayer (graded) structures [7-9], which consist either of a homogeneous chemical composition of a material, the microstructure and properties of which vary in depth, or combine essentially different in nature and mechanical properties of materials (metals, composites, ceramics) in one product to achieve the required complex of properties in general. It is well known that in order to provide sufficient impact anti-ballistic protection, armoured elements must have a high-strength and hardness of surface layer, which provides deformation and inhibition of piercing elements (bullets, shells), and deep layers with high ductility, which will prevent the cracking and destruction of the armour element.

The goal of this work was to study the possibility of obtaining multilayer (graded) structures of titanium-based materials, including the Ti-6Al-4V (VT6) alloy and metal matrix composites (MMC) based on it, as well as the T110 alloy, and the potential of their mechanical and protective properties. Two different approaches for the creation of such structures were investigated, one of which was based on the conventional casting and wrought technological approach followed by rapid heat treatment of the surface of the material (SRHT), and the another-on the technologies of blended elemental powder metallurgy.

\section{Materials and Experimental Procedures}

$\mathrm{Ti}-6 \mathrm{Al}-4 \mathrm{~V}$ (wt.\%) alloy was employed as a basic material for study, also $\mathrm{T} 110(\mathrm{Ti}-5.5 \mathrm{Al}-1.2 \mathrm{~V}-1 \mathrm{~V}-0.7 \mathrm{Zr}-3.8 \mathrm{Nb}-2 \mathrm{Fe}$; wt. \% ) alloy was studied. Materials (sheets or plates) with uniform or graded structures were obtained using conventional melting followed by subsequent thermomechanical processing and heat treatments, while multilayer structuresusing powder metallurgy approach.

Melting was performed by electron-beam cold hearth method (made in NVC 'Titan' from E.O. Paton Institute for electric welding, NAS of Ukraine). 
Obtained ingots of the Ti-6Al-4V and T110 alloys having diameter 200 $\mathrm{mm}$ were subjected $3 D$ hot pressing and then rolled into sheets or plates which thickness ranged from 4 to $14 \mathrm{~mm}$. Details of used technological approach are given in Refs. [10, 11]. Graded structural states were created with SRHT made by induction method [7-9] followed by final aging.

Another approach employed was based on blended elemental powders method of production of plate-specimens having dimensions $90 \times 90$ $\mathrm{mm}$ and thickness $10-25 \mathrm{~mm}$ having $2-3$ layers each of which differed in its chemical composition. Composition of different layers corresponded to $\mathrm{Ti}-6 \mathrm{Al}-4 \mathrm{~V}$ and MMCs on its base with $5-10 \%$ (by volume) of $\mathrm{TiB}$ or $\mathrm{TiC}$ hardening particles. Powder mixtures were done with particles titanium hydride, which size varied from $<40 \mu \mathrm{m}$ to $<150 \mu \mathrm{m}$, and hydrogen played a role of temporary alloying element activating sintering processes and cleaning particles surfaces from impurities [12, 13]. In the manufacture of mixtures of the specified composition, powder of 60Al-40V (wt.\%) master alloy was added, and in MMC layers $5-10 \%$ of the reinforcing particles of $\mathrm{TiC}$ or $\mathrm{TiB}_{2}$ (both having size less than $30 \mu \mathrm{m}$ ) were added. These mixtures were layer-by-layer filled to a mould, and pressed at a pressure of $150 \mathrm{MPa}$, forming the pre-forms consisting of several layers, and then sintered in vacuum at $1250{ }^{\circ} \mathrm{C}$ for 4 hours. The processes of desorption of hydrogen from hydrogenated titanium and the transformation of powder mixtures of each layer into massive chemically and microstructurally homogeneous materials (alloy or composites) with formation of a strong bond between layers of different composition took place during sintering. TiC particles during sintering process are inert to other powder particles, while $\mathrm{TiB}_{2}$ particles react with dehydrated titanium particles according to $\mathrm{TiB}_{2}+\mathrm{Ti} \rightarrow 2 \mathrm{TiB}$ reaction, forming a $\mathrm{TiB}$ phase in the appeared $\mathrm{Ti}-6 \mathrm{Al}-4 \mathrm{~V}$ matrix.

The microstructure of the materials on different stages of treatment and after testing was investigated by methods of optical (OM) and scanning electron microscopy (SEM). To determine the basic mechanical characteristics of the material of each individual structural state, their Vickers hardness, and tensile properties (according to the ASTM E8 standard) were measured, while for the multilayer (as well as graded) samples as a whole, their mechanical properties were measured by three-point flexure method (according to the ASTM E290 standard). Characteristics of ballistic resistance were evaluated for materials with different structural states (including graded and layered ones) in accordance with Ukrainian State Standards (DSTU V4103-2002 and DSTU 3975-2000) in the research and testing Laboratory of Weapons and Special Protective Materials of the Ivan Cherniakhovsky National Defence University of Ukraine, which is certified according ISO/IEC 17025:2006. The main characteristics of the weapons and ammunitions used during the ballistic tests are listed in Table 1.

As concerns the data in Table 1, we have to highlight the following points. 
Table 1. Characteristics of used ammunition and weapons.

Note that in the tests, we used ballistic barrels (BS) instead of standard weapons

\begin{tabular}{|c|c|c|c|}
\hline No. & Weapon & $\begin{array}{c}\text { Ammunition } \\
\text { (bullets) }\end{array}$ & $\begin{array}{l}\text { Bullet core diameter, } \\
\mathrm{mm}\end{array}$ \\
\hline 1 & Hand gun APS & 9Ч18 Pst & 7.2 \\
\hline 2 & Hand gun TT & 7.62425 Pst & 6.0 \\
\hline 3 & BS AK-47 & $5.45 Ч 39$ PS & 4.1 \\
\hline 4 & BS AK-47 & $5.45 Ч 39 \mathrm{PP}$ & 4.2 \\
\hline 5 & BS SVD & 7.62454 R LPS & 6.0 \\
\hline 6 & BS AKM & $7.62 Ч 39 \mathrm{BZ}$ & 6.1 \\
\hline 7 & BS SVD & $7.62 Ч 54$ В-32 & 6.1 \\
\hline
\end{tabular}

\begin{tabular}{|c|c|c|c|l|}
\hline No. & $\begin{array}{c}\text { Bullet } \\
\text { weight, g }\end{array}$ & $\begin{array}{c}\text { Bullet } \\
\text { speed,m/s }\end{array}$ & $\begin{array}{c}\text { Kinetic } \\
\text { energy, J }\end{array}$ & \multicolumn{1}{|c|}{ Bullet feature } \\
\hline 1 & 5.9 & $310-340$ & $340-370$ & 'Soft' steel core \\
2 & 5.5 & $380-410$ & $540-570$ & 'Soft' steel core \\
3 & 3.4 & $900-930$ & $1450-1550$ & 'Soft' steel core \\
4 & 3.61 & $900-930$ & $1500-1600$ & 'Hardened' steel core \\
5 & 9.6 & $840-880$ & $3200-3800$ & 'Soft' steel core \\
6 & 7.4 & $740-770$ & $2100-2200$ & 'Hardened' steel core + incendiary mix \\
7 & 10.4 & $830-860$ & $3500-3800$ & 'Hardened' steel core + incendiary mix \\
\hline
\end{tabular}

Table 2. Typical mechanical properties of investigated alloys (10 $\mathrm{mm}$ thick plates) after different regimes of heat treatment

\begin{tabular}{|c|c|c|c|c|c|c|}
\hline \multirow[b]{2}{*}{ No. } & \multirow[b]{2}{*}{ State } & \multicolumn{5}{|c|}{ Tensile properties } \\
\hline & & $\begin{array}{c}\text { Yield } \\
\text { strength, } \\
\mathrm{MPa}\end{array}$ & $\begin{array}{l}\text { Ultimate } \\
\text { tensile } \\
\text { strength, } \\
\mathrm{MPa}\end{array}$ & $\begin{array}{c}\text { Uniform } \\
\text { elongation, } \\
\%\end{array}$ & $\begin{array}{l}\text { Total } \\
\text { elonga- } \\
\text { tion, } \%\end{array}$ & $\begin{array}{l}\text { Reduction } \\
\text { of area, \% }\end{array}$ \\
\hline \multicolumn{7}{|c|}{ VT6 } \\
\hline 1 & Initial (after rolling) & 991 & 1021 & 1.21 & 6.54 & 30.2 \\
\hline 2 & $\begin{array}{l}\text { Annealed at } 880^{\circ} \mathrm{C}, 2 \mathrm{~h} \text {, } \\
\text { furnace cooling }\end{array}$ & 910 & 965 & 4.15 & 12.65 & 47.51 \\
\hline 3 & $\begin{array}{l}\text { Annealing } 1050^{\circ} \mathrm{C}, 1 \mathrm{~h} \text {, } \\
\text { furnace cooling }\end{array}$ & 895 & 924 & 3.22 & 8.24 & 28.35 \\
\hline 4 & $\begin{array}{l}\text { Annealed at } 880^{\circ} \mathrm{C} \\
(2 \mathrm{~h})+\mathrm{RHT}+550^{\circ} \mathrm{C}(6 \mathrm{~h})\end{array}$ & 1260 & 1295 & 2.64 & 7.91 & 32.4 \\
\hline \multicolumn{7}{|c|}{$\mathrm{T} 110$} \\
\hline 5 & Initial (after rolling) & 1040 & 1104 & 5.44 & 14.10 & 33.27 \\
\hline 6 & $\begin{array}{l}\text { Annealed } 880^{\circ} \mathrm{C}(1.5 \mathrm{~h}) \text {, } \\
\text { furnace cooling }\end{array}$ & 980 & 995 & 7.21 & 16.20 & 42.61 \\
\hline 7 & $\begin{array}{l}\text { Annealed } 880{ }^{\circ} \mathrm{C} \\
(1.5 \mathrm{~h})+\mathrm{RHT}+550{ }^{\circ} \mathrm{C}, 6 \mathrm{~h}\end{array}$ & 1300 & 1380 & 3.12 & 8.22 & 34.21 \\
\hline
\end{tabular}



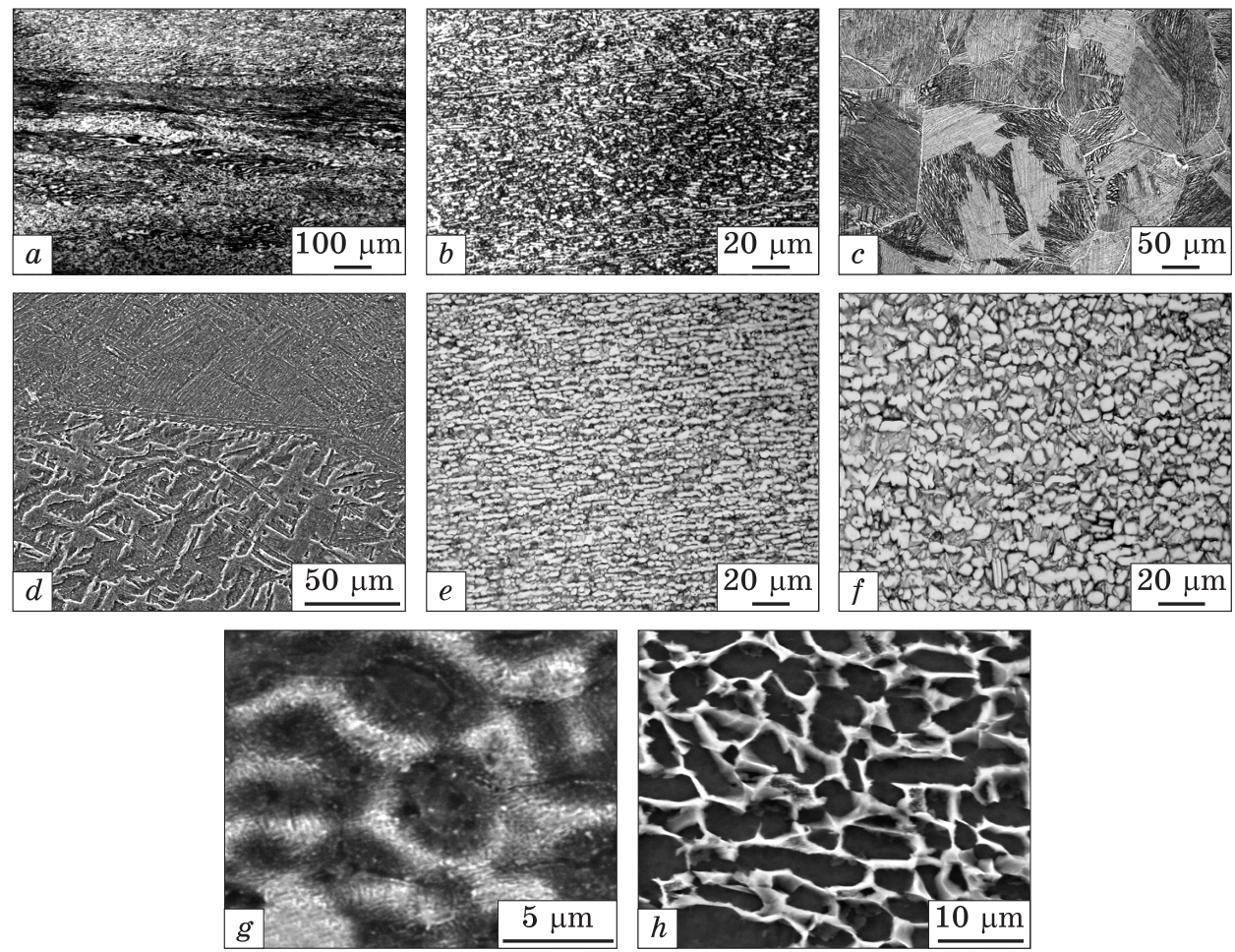

Fig. 1. The microstructure of investigated titanium alloys VT6 $(a-d)$ and T110 $(e-h)$ in the states: $(a, e)$ after rolling, $(b, f)$ after annealing at $880{ }^{\circ} \mathrm{C},(c)-$ after annealing at $1100{ }^{\circ} \mathrm{C},(d, g, h)$ - after SRHT. Here, OM $(a-f)$ and SEM $(g, h)$ methods are used

(i) The used ammunitions allowed to vary the kinetic energy of bullets in a wide range - from 340-570 $\mathrm{J}$ for hand guns (specific kinetic energy related to relevant calibre $12 \mathrm{~J} / \mathrm{mm}^{2}$ ) to $3200-3800 \mathrm{~J}$ (specific energy - up to $\approx 85 \mathrm{~J} / \mathrm{mm}^{2}$ ).

(ii) Used ballistic projectile elements can be divided into three types. The first-type projectiles (bullets): kinetic energy is exclusive damaging factor (bullets with 'soft' steel core, i.e. cores are not quenched for a high hardness, pts. 1-3 and 5 in Table 1). The second-type projectiles: bullets are characterized by two damaging factors - kinetic energy and high hardness of steel core (quenched for hardness over $700 \mathrm{MPa}$, pt. 4 in Table 1). The third-type projectiles: bullets are characterized by a combination of three factors: kinetic energy, hard steel core, and have an incendiary mix. 


\section{Results and Discussions}

\subsection{Cast and Wrought Alloys with Graded Structure}

Both alloys investigated in the cast and wrought state were characterized by microstructure partially transformed from coarse-grained lamellar, in which some residues of the primary grain boundaries were observed (Fig. 1, $a, e$ ). Subsequent annealing at the temperatures of two-phase $\alpha+\beta$-field allowed in VT6 alloy partially and in T110 completely transform intragrain $\alpha$-phase from lamellar to globular morphology (Fig. 1, $b, f$ ). Annealing at the temperature of single-phase $\beta$-field formed coarse-grained structure with lamellar $\alpha$-packets inside (Fig. 1, $c)$. These heat treatments caused in essential changes in tensile properties (Table 2).

Application of SRHT, as it was mentioned above, allowed to create in titanium alloys especial graded phase and structural states. Such phases and states are characterized, e.g., by combination of hardened surface layers (Fig. 1, $d, g$; their tensile properties are given in Table 2, pts. 4 and 7 for VT6 and T110, respectively). Such layers have more ductile substrate that has properties of annealed at the temperatures of two-phase $\alpha+\beta$-field (Fig. 1, $b, f$, pts. 2 and 6 in Table 2 for alloys VT6 and $\mathrm{T} 100$, respectively). Thus, the application of stabilizing and partially transforming deformed microstructure annealed at the temperatures of $\alpha+\beta$-field after thermomechanical processing ensured improvement of ductility in the both alloys as compared with just deformed states (cf. pts. 1 and 2 with pts. 5 and 6 in Table 2). Application of rapid heat treatment significantly improves the strength characteristics of the surface layer while keeping a sufficient reserve of plasticity (pts. 3 and 7 in Table 2 )*.

\subsection{Ballistic Tests}

\subsubsection{Alloy}

Typical example of ballistic tests of T110 (taking as an example plates with thickness $4.5,10$, and $14.5 \mathrm{~mm}$; every result was averaged from at least 3 shots) are presented in Table 3 . Analysis of presented data allows extracting as follow.

(i) There were no revealed material piercing (Fig. 2, $a, b$ ) during ballistic tests of $4.5 \mathrm{~mm}$ thick sheets for all types of microstructural states, using such hand guns as APS and TT with bullets of 'soft' steel

\footnotetext{
* Since the production of samples for tensile testing from plates subjected to surface treatment (SRHT) is problematic, specimens for these tests were subjected to bulk rapid heat treatment (RHT) under the regimes similar to SRHT. Details of such a bulk RHT are given in Refs. [14-16].
} 
Table 3. Results of ballistic tests for plates of $14.5 \mathrm{~mm}$ T110 alloy after various treatments

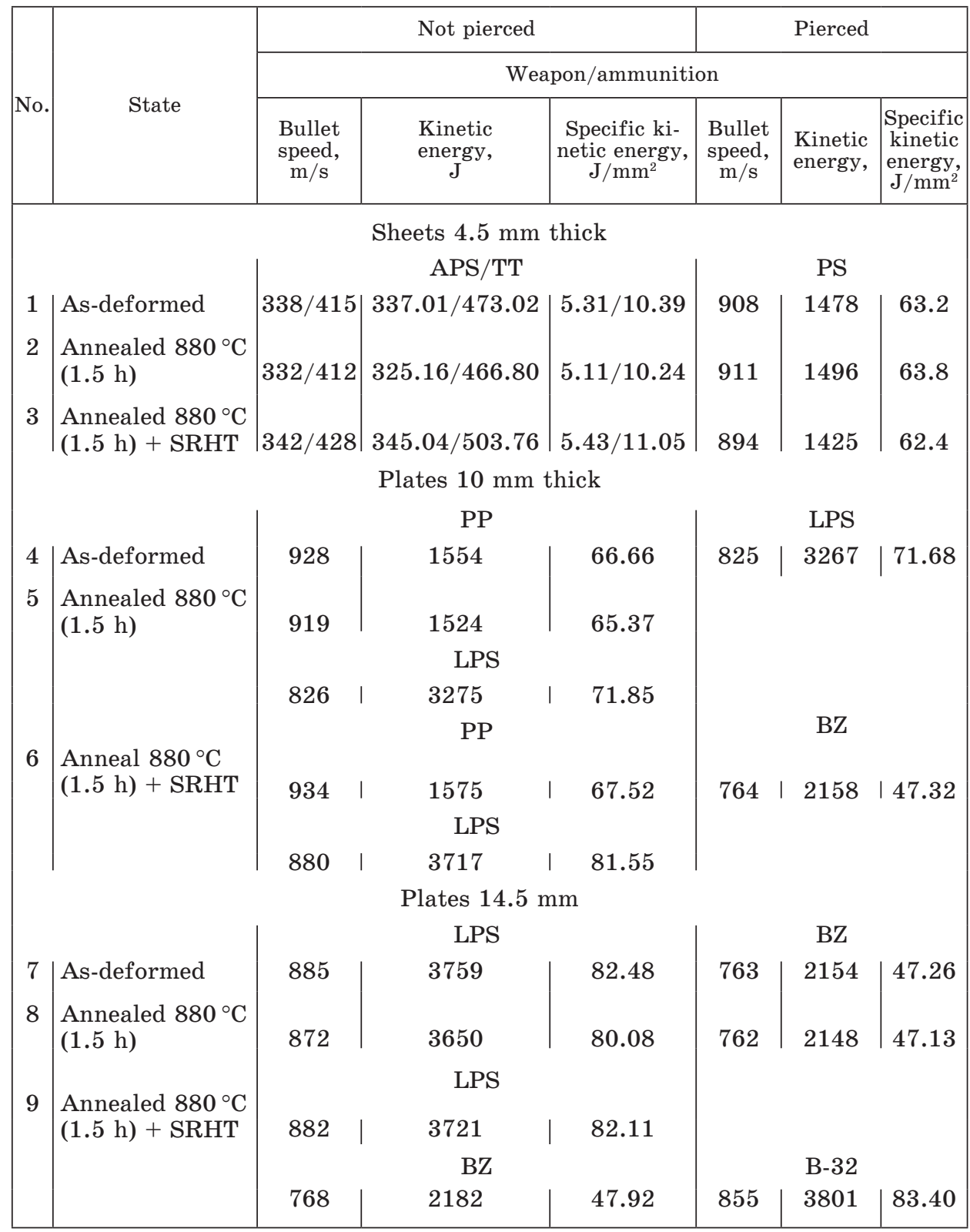

core of 9 and $7.62 \mathrm{~mm}$ calibres, respectively, having specific kinetic energy up to $\approx 11 \mathrm{~J} / \mathrm{mm}^{2}$. This case corresponds to the bullets of the first-type projectiles: see details in Table 1 (pts. 1 and 2) and Table 3 (pts. 1-3). At the same time, testing by PS bullets having three times 
higher kinetic energy (pt. 3 in Table 1) led to the complete piercing of sheets in all structural states.

(ii) The $10 \mathrm{~mm}$ thick plates in as-rolled state undergone testing by both PP bullets (second-type projectiles) having specific kinetic energy 65-67 $\mathrm{J} / \mathrm{mm}^{2}$, and LPS bullets (first-type projectiles) with higher specific kinetic energy - above $71 \mathrm{~J} / \mathrm{mm}^{2}$. The same material but in annealed state, which were characterized by equilibrium phase composition and equiaxed microstructure of globular type (Fig. 1, $f$ ) and have better characteristics of ductility, was pierced by bullets of the secondtype projectiles. Treated by SRHT plates having graded microstructure with hardened surface layer also were not pierced by both types of above-mentioned bullets. However, impact ballistic testing of these plates with graded microstructure by bullets of the third-type projectiles caused to complete piercing.

These results allow to assert that T110 alloy can provide enough antiballistic resistance against bullets of the (above-mentioned) first and second types in $10 \mathrm{~mm}$ plate in microstructural states having some special balance of strength and ductility obtainable by thermomechanical processing (accumulating some residual stresses), or by special heat treatment, namely SRHT. At the same time application of annealing at the temperature of $\alpha+\beta$-field despite of usually desired for many practical applications transformation into globular type of microstructure $[1,6]$, however, has obviously insufficient strength characteristics compared to two other structural states.

(iii) Testing of $14.5 \mathrm{~mm}$ thick plates in two structural states just as-rolled and after subsequent annealing at $880^{\circ} \mathrm{C}, 1.5 \mathrm{~h}$ overcome ballistic impact tests with high-energy first-type projectiles (LPS) and second-type projectiles (PP) (pts. 7 and 8 in Table 3). While tests by thirdtype projectiles having relatively low specific kinetic energy (up to $48 \mathrm{~J} / \mathrm{mm}^{2}$, BZ - pt. 6 in Table 1, and pt.7 in Table 3) caused in piercing. Ballistic impact tests by third-types projectiles (bullets including BZ) overcome plates surface hardened by SRHT (pt. 9 in Table 3), which was pierced by high-energy (having specific kinetic energy over $83 \mathrm{~J} /$ $\mathrm{mm}^{2}$ ) third-type projectiles that combine all three affecting factors.

From the foregoing it can be asserted that the T110 alloy could achieve sufficient resistance against piercing by the elements of the third-type projectiles in case of a such balance between strength and plasticity, which can be provided as a result of special heat treatment (SRHT) gradient microstructure only.

\subsubsection{VT6 Alloy}

Ballistic tests of $4.5 \mathrm{~mm}$ thick sheets of this alloy showed actually the similar results like sheets of T110 alloy of the same thickness. In other words, they withstood tests by the first-type projectiles having low spe- 
cific kinetic (hand guns APS and TT in Table 1, cf. $c$ and $d$ with $a$ and $b$ in Fig. 2). Visible difference was found when tested $10 \mathrm{~mm}$ plates of VT6 alloy (all types of microstructures including subjected SRHT) when them were pierced by projectiles of both first (having high specific kinetic energy) and second type (PP) (Fig. 2, $g$ and $h$ ). In other words, the best achieved balance of strength and ductility of upper layer in this alloy (pts. 2 and 4 in Table 2), contrary to T110 alloy of the same thickness (pts. 6 and 7 in Table 2), is not enough to ensure ballistic resistance against such projectiles. Also $\mathbf{1 4 . 5} \mathrm{mm}$ thick plate of this VT6 alloy undergo tests with above projectiles, however, even in gradient state (after SRHT) such plates were pierced by third-type projectiles with low specific kinetic energy (BZ, Fig. $2, k$ and $l$ ).

Thus, comparing testing results for T110 and BT6 alloy sheets of the same thickness, we can assert as follow.

(i) At a thickness of $4.5 \mathrm{~mm}$, actually they are equally resistant during testing with the first-type projectiles possessing small kinetic energy (APS and TT).

(ii) Tests for other types of the projectiles (first type with high kinetic energy as well as second and third types) showed T110 allow has irrefutable advantageous over the BT6 alloy.

(iii) The best ballistic resistance goes to the T110 alloy with graded microstructure generated via the SRHT.

\subsubsection{Peculiarities of the Damaged Area Depending on the T1 10 Ti-Alloy Structure}

We have to note that in spite of a large number of the works dealing with investigation of ballistic resistance of titanium alloys, there are no works paying attention to the microstructure effect. Only works [5, 17] showed that globular-type microstructure of $\mathrm{Ti}-6 \mathrm{Al}-4 \mathrm{~V}$ alloy is more resistant as compared with the lamellar-type microstructure. Such a result [17] was obtained for projectiles of the calibre of $12 \mathrm{~mm}$ projectiles at a velocity of $\approx 1000 \mathrm{~m} / \mathrm{s}$. Similar conclusion (about the advantage of the globular-type microstructure) follows from the analysing a lot of tests for the same alloy after different types of thermomechanical treatment (i.e., with different microstructure) [5]. Above-mentioned and our results unambiguously indicate about significant influence of the microstructure of titanium alloys on their resistance with respect to the impact ballistic damage or even destruction.

First of all, we compared peculiarities of the deformation and damage of the T110 alloy sheets during their piercing depending on the microstructure type. Figure 3 represents typical examples, where one can see as follow. In case of the piercing of the sheets in the as-rolled state (Fig. 1,e), there is a cracking (delamination) of the metal along the origin 
O.M. Ivasishin, P.E. Markovsky, D.G. Savvakin, O.O. Stasiuk, V.A. Golub et al.
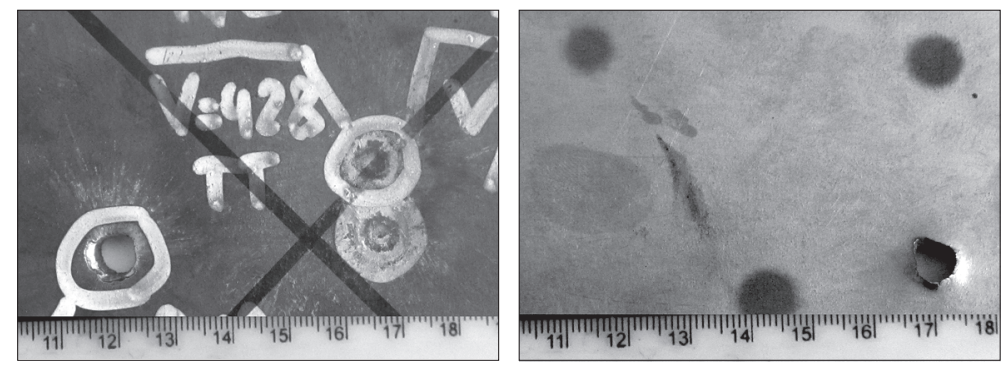

$a$

\section{b}
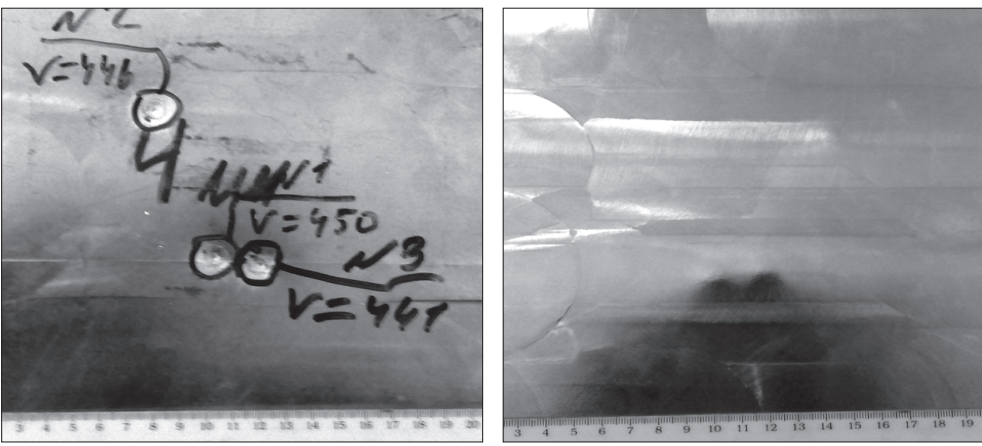

$d$

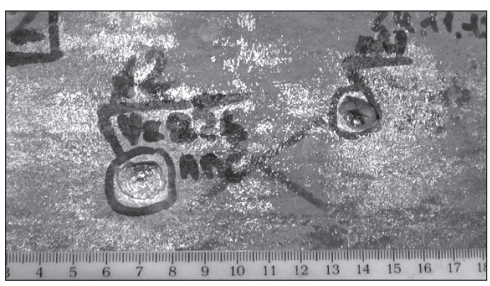

$e$

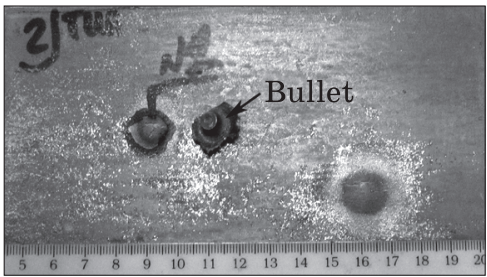

f

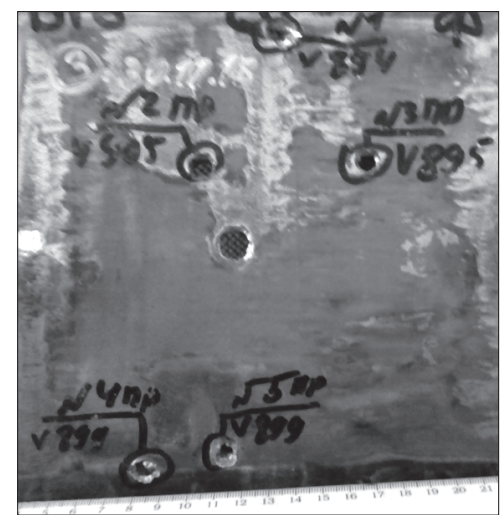

g

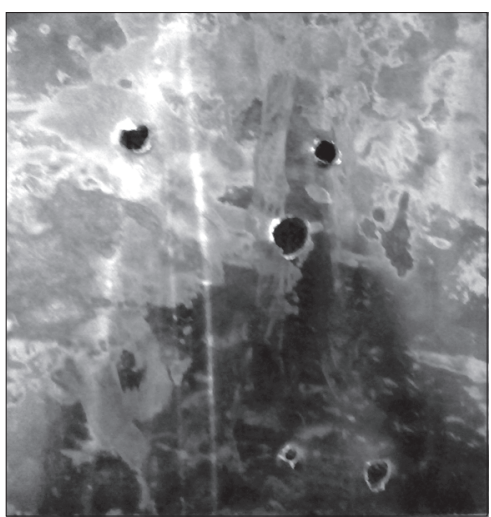

h 


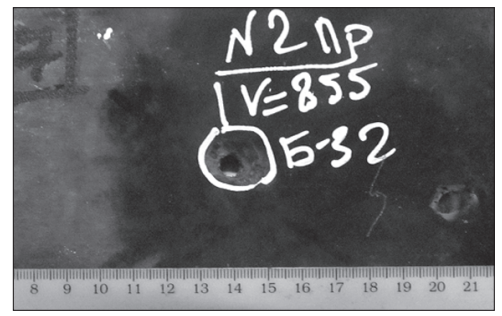

$i$

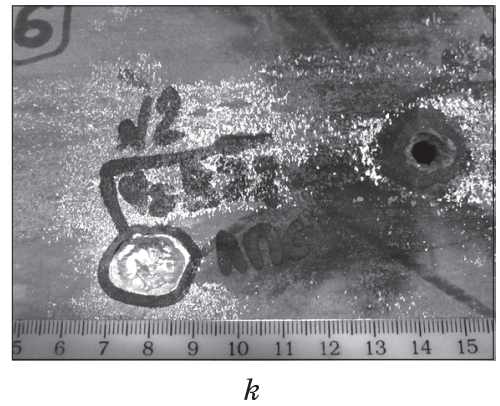

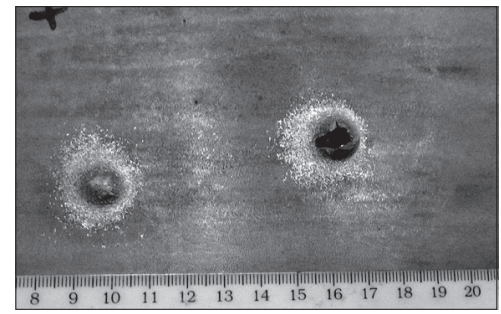

$j$

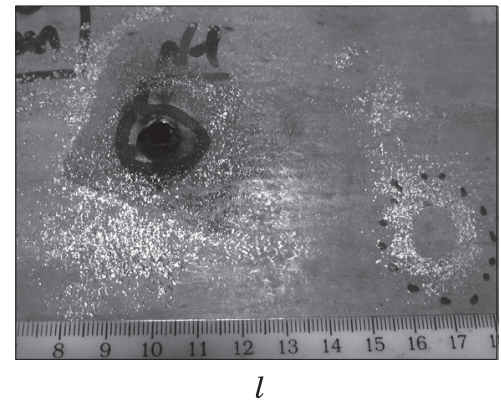

Fig. 2. Typical plates of T110 $(a, b, e, \mathrm{f}, i-l)$ and VT6 $(c, d, g, h)$ alloys with thickness of $4.5 \mathrm{~mm}(a-d), 10 \mathrm{~mm}(e-h)$, and $14,5 \mathrm{~mm}(i-l)$ after testing via different types of ammunition. Front $(a, c, e, g, i, k)$ and back $(b, d, f, h, j, l)$ sides are imaged
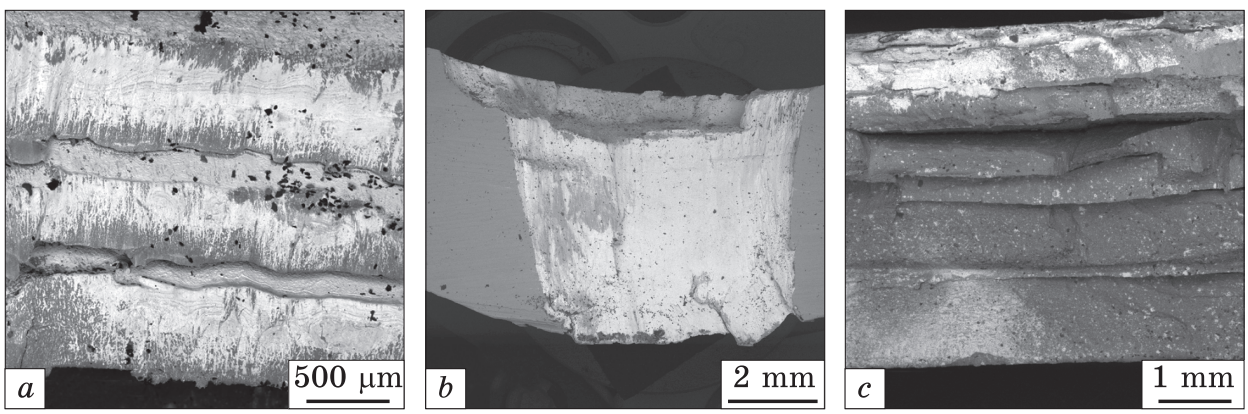

Fig. 3. General view (SEM images) of pierced zones in the T110 alloy plates of $4.5 \mathrm{~mm}$ thickness after testing by the first-type bullets (LPS): $(a)$ - state after rolling, $(b)$ - annealed for the globular microstructure, $(c)$ - after SRHT

boundaries of non-recrystallized grains. However, the damage is generally plastic, indicative of which is the deflection of certain layers along the bullet motion (Fig. 3, a). The globular and recrystallized structure after the annealing (Fig. 1, $f$ ) also underwent plastic deformation, but (in contrast to the as-rolled state) homogeneously (Fig. 3, $b$ ). One can see the extremely brittle fracture of the hardened SRHT structure accompanied with fragmental delamination and cleavage (Fig. 3, ). 

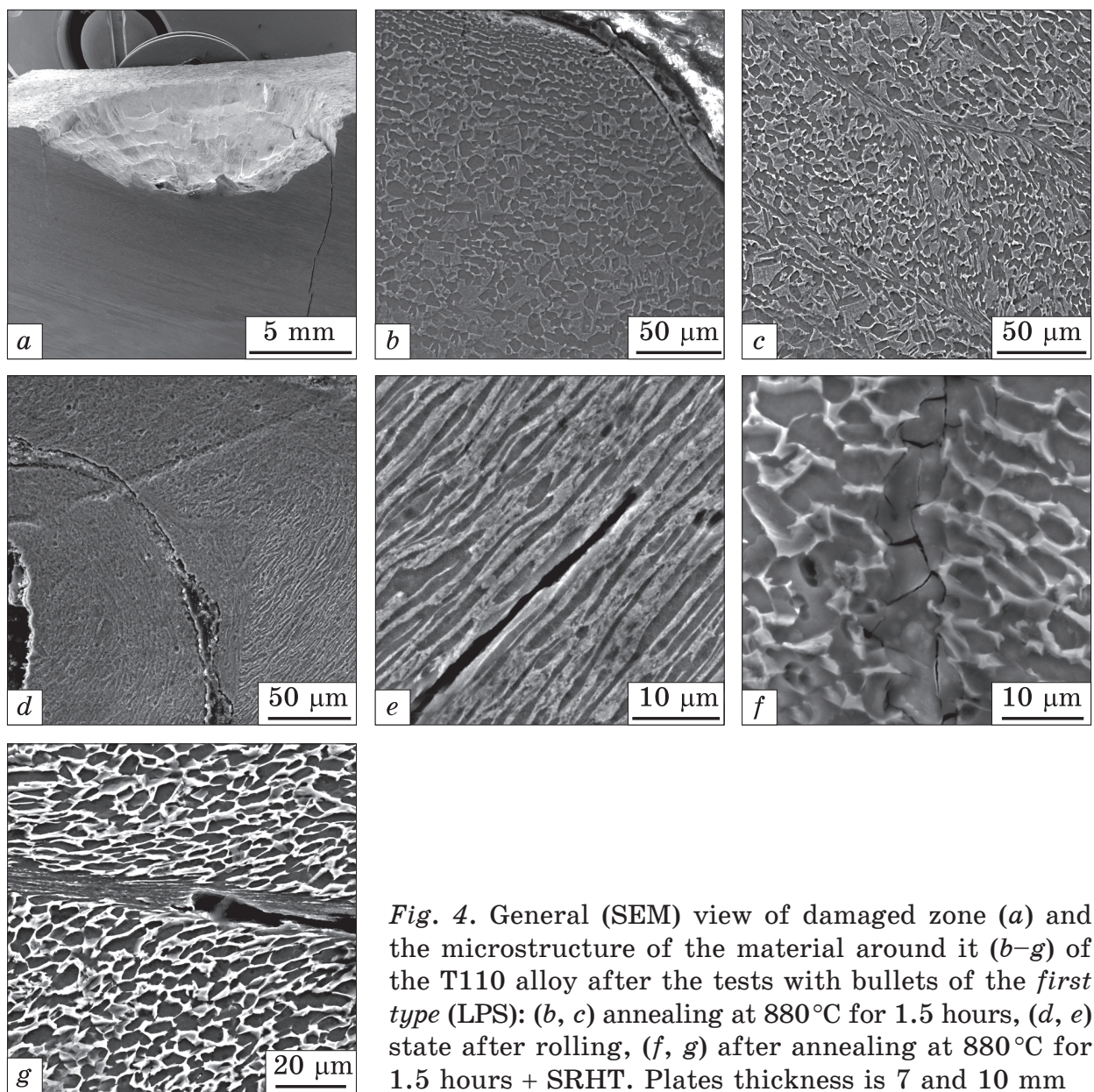

Fig. 4. General (SEM) view of damaged zone $(a)$ and the microstructure of the material around it $(b-g)$ of the T110 alloy after the tests with bullets of the first type (LPS): $(b, c)$ annealing at $880^{\circ} \mathrm{C}$ for 1.5 hours, $(d, e)$ state after rolling, $(f, g)$ after annealing at $880^{\circ} \mathrm{C}$ for 1.5 hours + SRHT. Plates thickness is 7 and $10 \mathrm{~mm}$

Detailed analysis of the alloy microstructure in the areas close to the bullet-formed channels showed the following. The first-type projectiles generate a 'crater' (Fig. 4,a), in the upper part of which the material adjacent to the edge can even have not an observed deformation (Fig. $4, b$ ). That is the projectile not only undergoes deformation when gets contact with the sheet surface, but rather partially 'cut out' a certain part of the material. Adiabatic shear bands (ASB), which lie at an angle of $30-45^{\circ}$ upwards, are observed in the areas closely the region of the projectile piercing (Fig. 4, c). In the sheets, tested just after the rolling, we observed both cracking (rather along the not-recrystallized but elongated in rolling direction initial $\beta$-grains) and significant plastic deformation of the material between the cracks (Fig. 4, $d, e$ ). The structural features of the SRHT-processed sheets consisted in the formation of the branched net of the small cracks in the upper heat-hardened 

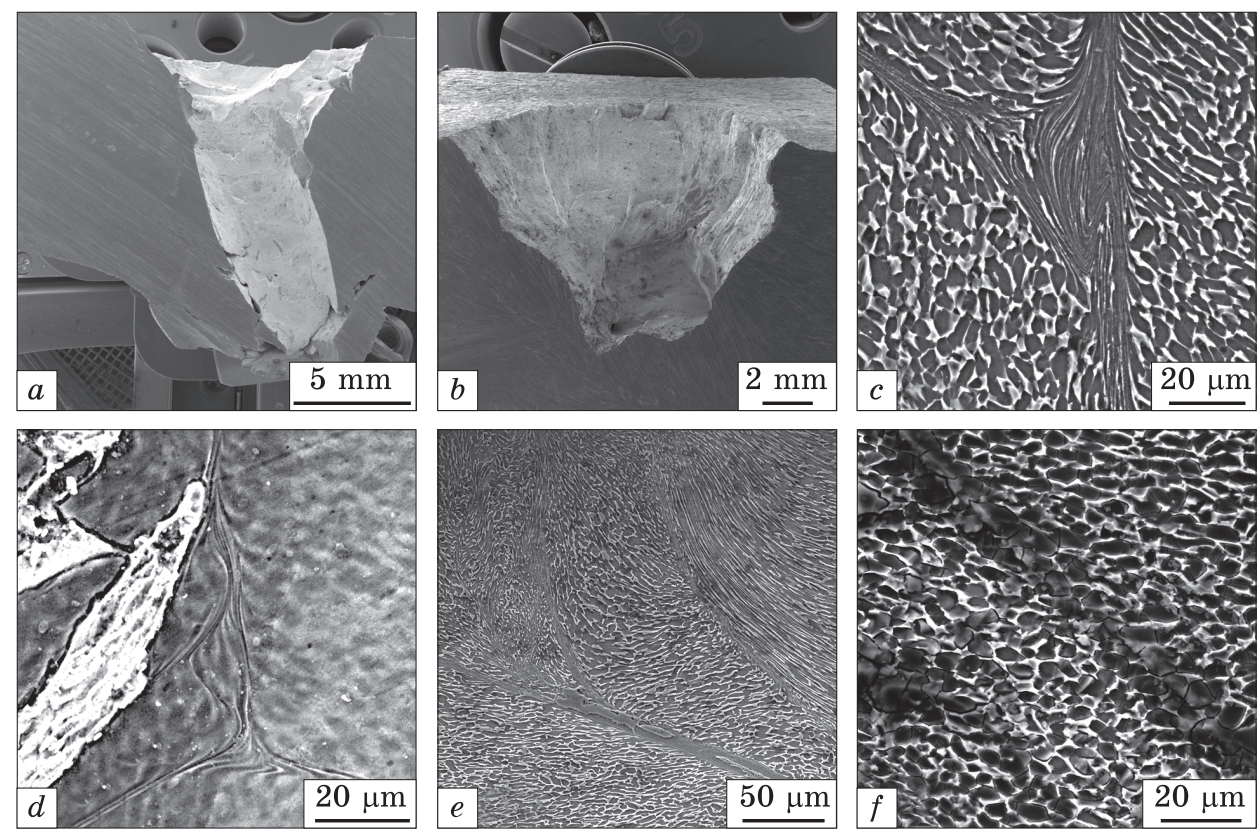

Fig. 5. SEM-images of damaged zone $(a, b)$ and microstructure of the material (10 $\mathrm{mm}$ thick plate) around it $(c-f)$ for T110 alloy after tests with bullets of the second type $(\mathrm{PP})$, where $(a, c)$ correspond to the annealing at $880^{\circ} \mathrm{C}$ for 1.5 hours, $(b, d-f)-$ annealing at $880^{\circ} \mathrm{C}$ for 1.5 hours + SRHT

layer (Fig. 4, $f$ ), while in the lower ductile layers, we observed the formation of the ASB similar to the case of annealing at $880^{\circ} \mathrm{C}$, however, these bands degenerated into the cracks (Fig. 4, g).

In case of the tests with the second-type projectiles, in the upper part of the damage area, a 'crater' also appears. However, after a possible 'cut out' of the material from the surface and the delamination of the copper coating and the melting of the lead filling of the bullet*, the hard steel core, as a rule, has changed the angle of its penetration deep into the sheet (Fig. 5,a). That is the shape of the damaged area was different when the first- and second-type projectiles used. At the relatively soft unhardened steel cores, whose hardness was approximate to the hardness of titanium sheets, these cores were deformed (element $A$ in Fig. 6). Whereas the core, hardened with hardness more than twice as high as titanium alloys, were deformed partially (element $B$ in Fig. 6), either did not deform or broke during tests (elements $C$ in Fig. 6). At that, the branched net of ASB appears in the annealed alloy sheets

* In all cases, as shown by the local microanalysis, the surfaces of the 'craters' and the formed by the hardened cores of the channels were covered with molten lead. Sometimes, on the surface of 'craters', traces of copper shells of bullets were observed. 


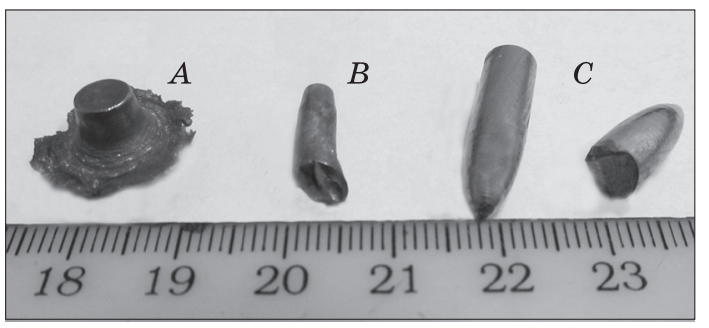

Fig. 6. Steel core of bullets after the test, where $A$ corresponds to LPS, $B-$ PP, $C-$ B-32 (left) and BZ (right)
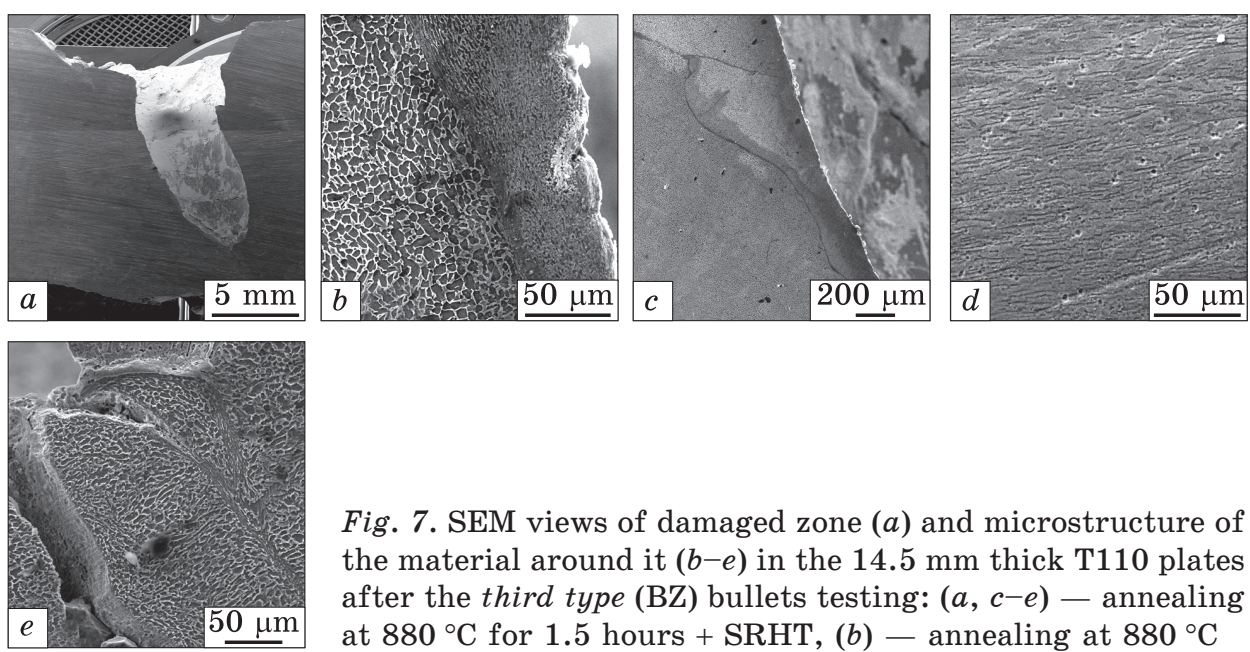

Fig. 7. SEM views of damaged zone $(a)$ and microstructure of the material around it $(b-e)$ in the $14.5 \mathrm{~mm}$ thick T110 plates after the third type (BZ) bullets testing: $(a, c-e)-$ annealing at $880^{\circ} \mathrm{C}$ for 1.5 hours + SRHT, $(b)-$ annealing at $880^{\circ} \mathrm{C}$

(Fig. 5, c). The difference in resistance to PP bullets of purely 'ductile' material (after annealing) and after additional surface hardening (SRHT) is well illustrated by a comparison of Figs. 5, $a$ and $b$. In the latter case, the steel hardened core, judging by the form and the depth of the formed channel, deviates at a greater angle and sooner loses its kinetic energy. In the microstructure of the annealed material in the regions adjoining the area of the damage, an extensive net of ASB is formed (Fig. 5, c), which indicates about an intense dynamic deformation. Similar ASB against a background of cracks were also observed in the SRHT processed material in the pier part of the sheets (around the 'crater'; Fig. 5, d). In the lower ductile layer, the microstructure was also characterized by the ASB grid (Fig. 5. e) with small cracks observed in the transition zone between the thermally strengthened surface and the annealed layer in the middle of these bands (Fig. 5, $f$ ).

Typical examples of the structure of T110 alloy with different microstructure after ballistic damage with the third-type projectiles are represented in Fig. 7. It is clearly seen in Fig. 7, $a$, that the channel formed in the SRHT-processed sheet from the BZ bullet is very similar to that formed after the test by the PP bullets (Fig. 5, $a$ ). The difference 
lies in its size, as well as in the fact that its surface is covered not only by lead, but also by the remnants of a burning incendiary mixture. The principal difference from the previous case was that in the annealed material in the area near the upper crater, a specific structure along the channel wall was observed (Fig. $7, b$ ). This may be the result of more intense heating of the metal (possibly, until its melting and reaction of the liquid metal with bullet materials) because of the joint action of kinetic energy, solid core, and incendiary mix. In the surface heatstrengthened layer of SRHT-treated sheets, mainly cracks were observed (Fig. 7, b), but there were not detected changes in the structure of the area adjacent to the channel (Fig. 7, d). In the deeper 'ductile' layer of the SRHT-processed sheets, down to the bottom of the bullet-formed channel, the ASB and associated cracks were observed (Fig. 7,e).

Thus, both the character of damage of the sheets and structural changes in the metal of the T110 alloy in the areas adjacent to the damage zone are determined by the character of the impact of damage factors and by the structure of the alloy.

\subsubsection{Generalization of the Results and Conclusions}

J. Fanning performed the most detailed investigations $[3,18]$ of an effect of the thickness of different titanium-contained sheets on such characteristic as a velocity of the bullet, when probability of the piercing is $50 \%$ $\left(V_{50}\right)$. He showed that when one type of the bullets is used (calibre $7.62 \times 35.6 \mathrm{~mm}$, mass $7.97 \mathrm{~g}$, 'soft' steel core), the $V_{50}$ parameter is linearly-dependent on the thickness of the sheets, moreover the best results showed just $\mathrm{Ti}-6 \mathrm{Al}-4 \mathrm{~V}$ alloy [3]. The bullets used by Fanning are close to those we used: LPS bullets of $7.62 \times 54 \mathrm{~mm}$ calibre and $9.6 \mathrm{~g}$ mass. That is at the same velocity, our bullets possessed 1.2 times higher kinetic energy. Herewith, as we already mentioned above, author did not detect any relationship to the microstructure. Since we used different structural states and essentially different weapons and ammunitions, we used another approach to generalize the obtained results, viz. we represented them on the diagram depending on the specific kinetic energy of the bullets and the thickness of the sheets. Just this approach enables comparing the results of tests not only for different materials but also for different fire weapons, and was proposed and used in our previous works [11, 25].

Results of this analysis are presented in Fig. 8, where we can see three principally different zones denoted via the lines $(1,2,3)$. The line 1 defines the necessary for protection ensured thickness of the sheets of the T110 alloy, depending on the specific kinetic energy of the firsttype projectiles, which have a thermally not-hardened metal (steel) core, that is, a core with hardness does not exceed the hardness of the surface layers of the titanium alloy (approximately 350-370 HV). The line 2 determines the necessary thickness of the T110 alloy sheets depending 


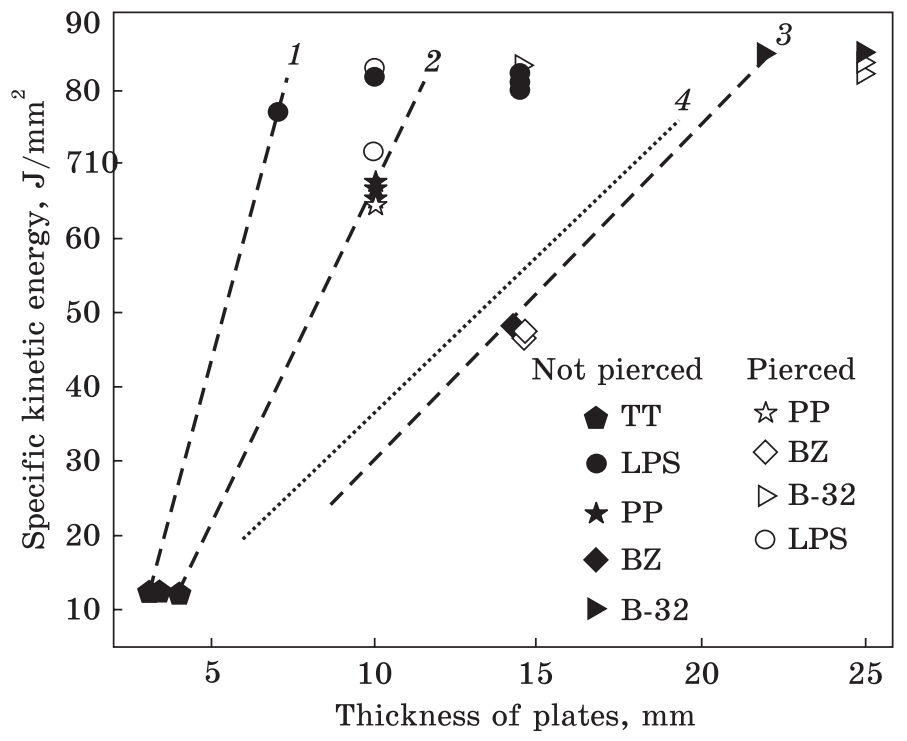

Fig. 8. Influence of thickness of T110 alloy plates in different structural-phase states on their resistance against piercing depending on specific kinetic energy of different kinds of bullets. Here, 1 - corresponds to the testing by bullets with 'soft' (not thermally hardened) steel core (first type), 2 - testing by bullets with 'hard' (thermally hardened for hardness of more than $700 \mathrm{HV}$ ) steel core (second type), 3 - bullets with thermally strengthened steel cores and an inflammatory mixture (third type), and 4 - the dependence obtained by J. Fanning [3, 18] for $7.62 \mathrm{~mm}$ calibre bullets with soft steel cores

on the specific kinetic energy of the second-type projectiles, which have a thermally strengthened steel core with a hardness significantly exceeding the hardness of the thermally strengthened top-layer of the T110 alloy (i.e., more than $700 \mathrm{HV}$ ). The line 3 corresponds to the ballistic test condition with the third-type projectiles, where thermally hardened steel core is combined with an inflammable mixture. The areas below and to the right of the given straight lines concern such values of the thickness of the T110 titanium alloy sheets, which will provide them to be impenetrable for the bullets (projectiles) of the corresponding type and kinetic energy. Analysing the diagram, one can clear see that the protection from the piercing depends not only on the kinetic energy of the bullets (in proportion to which the required thickness of the sheets increases), but also on the type of projectiles (bullets). Particularly, it depends on the addition to a purely kinetic effect (line 1) such a factor as the hardness of the core (line 2), and, especially, the combined action of hardness and the incendiary mix (line 3 ).

In other words, when we add 'additional' factors, in order to be not pierced, the thickness of the sheets should increase. Regarding the impact factor of the structural state, it should be noted that the best re- 
sults of the stability of the T110 alloy correspond exactly to the SRHTtreated sheets (most of the filled symbols in Fig. 8).

It should be noted separately that the results (line 4 in Fig. 8) obtained earlier by J. Fanning [3] mainly for the Ti-6Al-4V alloy (similar to VT6) are much worse than those we obtained for analogous projectiles (line 1). Thus, in case of a specific kinetic energy of, e.g., $\approx 80-85 \mathrm{~J} / \mathrm{mm}^{2}$ (LPS bullets), a sufficient armour resistance can be provided by the only $7 \mathrm{~mm}$ thick sheets of SRHT-treated T110 alloy. Whereas, according to Ref. [3], the sheet of the Ti-6Al-4V alloy should be at least of $18 \mathrm{~mm}$ thick, that is 2.5 times higher.

\subsection{Layered Structures, Obtained via the Powder Metallurgy Method}

\subsubsection{Microstructure and Mechanical Properties}

In a process of manufacturing multilayer structures via the powder method*, during the sintering of blanks, the development of diffusion processes (including, due to hydrogen's effect on the material) leads to the formation of a chemically and microstructurally homogeneous $\mathrm{Ti}-$ $6 \mathrm{Al}-4 \mathrm{~V}$ matrix in each layer (Fig. 9). During the cooling, in each layer, a structure of a lamellar type with dispersed grains (from $40-50 \mu \mathrm{m}$ in the matrixes of composites up to $80-120 \mu \mathrm{m}$ in the alloy) is formed, at the same time, layers of the alloy and the alloy-based composites are characterized by different residual porosity. In the layers, corresponding to the composites, the TiC particles (Fig. 9, $b$ ) and the needle-shaped TiB crystals (Fig. 9, $c$ ), formed in the process of high-temperature exposure, are distributed uniformly in matrix. At that, the volume content of pores in composites with $5-10 \% \mathrm{TiC}$ is $3-4 \%$, which is close to the content of the pores in the $\mathrm{Ti}-6 \mathrm{Al}-4 \mathrm{~V}$ alloy $(1.8-3.6 \%)$, while the porosity of $\mathrm{TiB}$ composites is significantly higher $(4.5-8 \%)$, increasing with an increase in the content of the boride phase. An optimization of the parameters of the powder process $[19,20]$, aimed to reduce porosity and achieve similar values of the shrinkage of each layer, provided sufficient adhesion and a strong connection between the alloy layers and composites without the formation of cracks and additional porosity at the layer interfaces (Fig. 10). Such features of the structure are indispensable conditions for achieving high mechanical and protective characteristics of multilayer material in general.

In order to determine the prospects for the application of such layered structures as protective armour components, first of all, the complex of their mechanical characteristics was estimated.

\footnotetext{
* Phase-transformation processes, alloy formation and formation of microstructure of the layered states are considered in d etail in Refs. [22-24].
} 

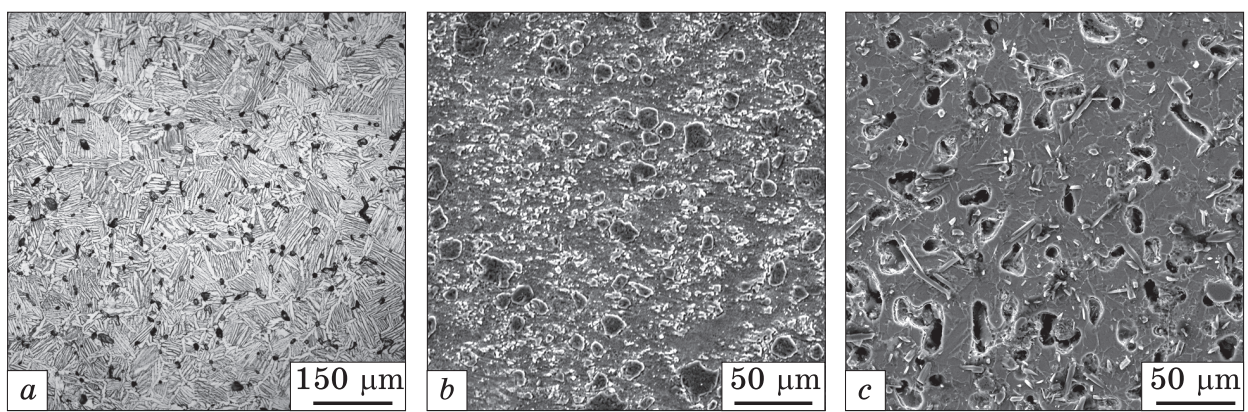

Fig. 9. Typical (OM) images of microstructure of individual layers of $\mathrm{Ti}-6 \mathrm{Al}-4 \mathrm{~V}$ alloy $(a)$ along with $\mathrm{Ti}-6 \mathrm{Al}-4 \mathrm{~V}-10 \% \mathrm{TiC}(b)$ and $\mathrm{Ti}-6 \mathrm{Al}-4 \mathrm{~V}-10 \% \mathrm{TiB}(c)$ composites
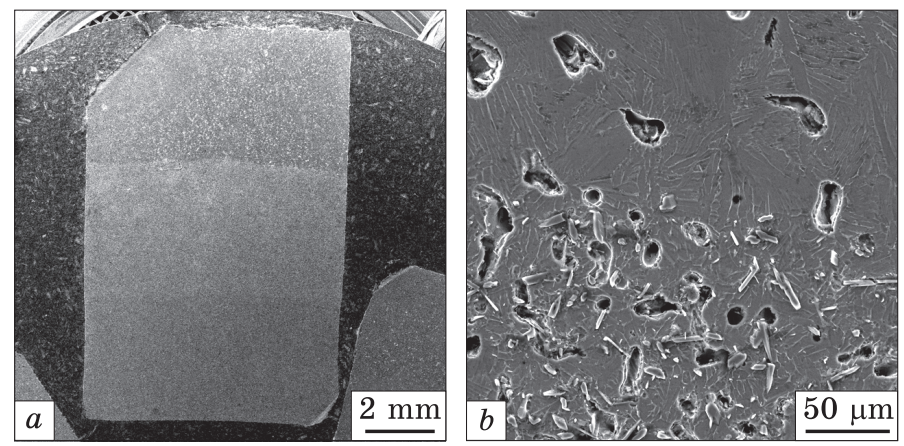

Fig. 10. OM-image of macrostructure of the three-layer material (Ti-6Al-4V alloy along with composites with $5 \%$ and $10 \%$ of TiV) $(a)$ and the distribution boundary between the layers $(b)$

The basic mechanical characteristics were determined both separately for each sintered material and for two-layer samples that combine the Ti-6Al-4V alloy layer with various composites based on it (Table 4). Data on mechanical characteristics are contained in Table 4, along with a critical parameter such as residual porosity of sintered materials, which in many cases is a determining factor for mechanical properties of individual layers and multilayer samples. The individual Ti-6Al-4V alloy layer demonstrates strength at tensile tests at the standard level for the corresponding cast and deformed material (969-1034 MPa). At the same time, the elongation of the sintered alloy is somewhat lower than the standard values $(7.2-8.3 \%$ vs. $>10 \%)$ due to the presence of porosity, which was $1.8-3.6 \%$. The reason for the different final porosity of the Ti-6 Al- $4 \mathrm{~V}$ alloy in various samples is the need for a controlled shrinkage of certain layers via the changes in the parameters of the powder process for providing the integrity of the multilayer structures $[19,20]$. That is why the alloy neighbouring to the layers of the carbide and boride composites had a different porosity. 
Fig. 11. The stress-strain curves for three-layered samples $(10 \%$ TiC composite, $5 \%$ TiC composite, $\mathrm{Ti}-6 \mathrm{Al}-4 \mathrm{~V}$ alloy) showing a change in mechanical characteristics at different thicknesses of individual layers. Here, we do not adduce details, since the material is in a patenting process now

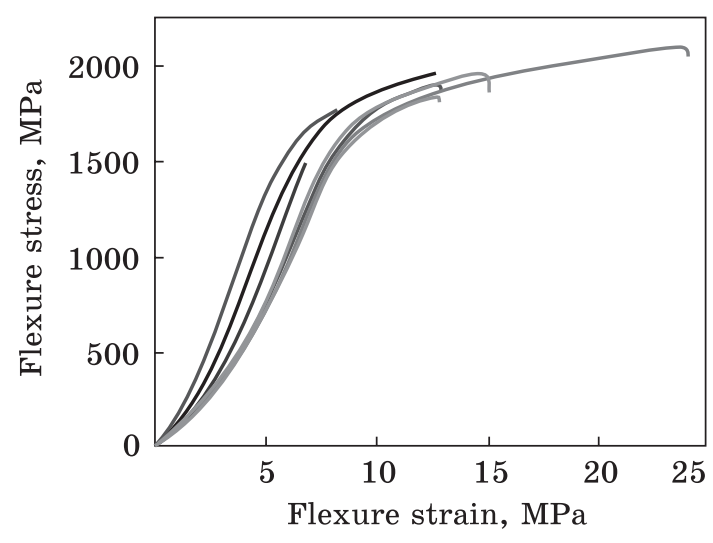

The porosity factor becomes especially critical when boride particles are added to the $\mathrm{Ti}-6 \mathrm{Al}-4 \mathrm{~V}$ matrix. The presence of these particles affects the processes of sintering, increasing the volume content of pores in the formed composites. An increase of the content of high-modulus $\mathrm{TiC}$ and $\mathrm{TiB}$ particles results in an increase of the hardness and strength of the formed composites [21] as compared with the Ti-6Al-4V alloy. However, in our case, only the composite strengthened with carbide particles has a tendency to increase the hardness, as well as an increase of the strength and plasticity during testing via a three-point flexure method. In contrast, for composites with boride particles, this effect is suppressed by an increase in the volume content of pores (Table 4). In tensile tests, the elongation and strength of the resulting composites are sharply reduced due to the presence of hard carbide or boride particles and residual pores. In case of such method of the loading, the composites are destroyed practically brittle even before reaching the yield strength.

Table 4. The main mechanical characteristics of materials of individual layers and two-layer samples consisting of Ti-6Al-4V alloy and composites on its basis

\begin{tabular}{|c|c|c|c|c|c|c|}
\hline \multirow{2}{*}{ Material } & \multicolumn{4}{|c|}{ Individual layers } & \multicolumn{2}{c|}{$\begin{array}{c}\text { Two-layer samples } \\
\text { (composite layer/ } \\
\text { Ti-6Al-4V layer) }\end{array}$} \\
\cline { 2 - 7 } & $\begin{array}{c}\text { Porosity, } \\
\%\end{array}$ & $\begin{array}{c}\text { Hardness, } \\
H V\end{array}$ & \multicolumn{2}{|c|}{ Tensile properties } & \multicolumn{2}{c|}{$\begin{array}{c}\text { Three-point flexure } \\
\text { method testing }\end{array}$} \\
\cline { 4 - 7 } & & & UTS, MPa & $\varepsilon, \%$ & $\begin{array}{c}\text { Flexure } \\
\text { strength, MPa }\end{array}$ & Strain, \% \\
\hline Ti-6Al-4V & $1.8-3.6$ & $299-345$ & $969-1034$ & $8.3-7.2$ & $1680^{*}$ & $15.4^{*}$ \\
Ti-6Al-4V-5TiC & 3.8 & 333 & 708 & $<1$ & 2140 & 18.5 \\
Ti-6Al-4V-10TiC & 3.6 & 373 & 618 & 0.1 & 2158 & 14.0 \\
Ti-6Al-4V-5TiB & 4.5 & 327 & 847 & 0.1 & 1710 & 10.3 \\
Ti-6Al-4V-10TiB & 8 & 324 & 512 & 0.1 & 1660 & 9.0 \\
\hline
\end{tabular}

* Flexure tests for individual alloy layer. 


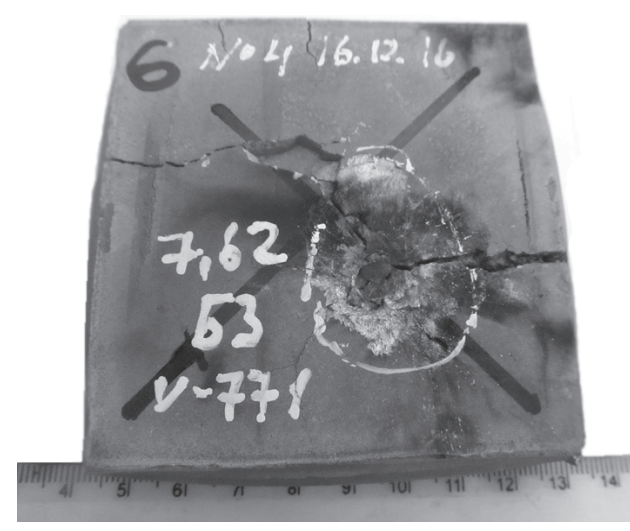

$a$

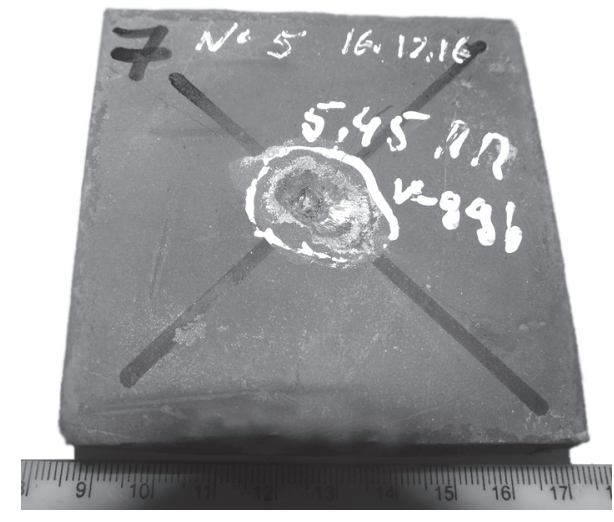

$b$

Fig. 12. Experimental samples with two- $(a)$ and three-layered $(b)$ structures after ballistic tests via PP $(a)$ and $\mathrm{BZ}(b)$ type of bullets

On the other hand, the loading scheme for the tests via the threepoint flexure is more in line with the loading plan with a ballistic impact, so this method allows more adequate prediction of the material behaviour during ballistic testing. From the data in Table 4, it can be concluded that, with the involved method of manufacturing multilayer samples (cold pressing and vacuum sintering without applying deformation processes), greater prospects for achieving high mechanical (and, consequently, protective) characteristics have composites hardened with TiC particles than TiB ones. In addition, from Table 4 it can be seen that the creation of a two-layer structure during tests on a three-point flexure, in comparison with an individual $\mathrm{Ti}-6 \mathrm{Al}-4 \mathrm{~V}$ alloy, gives a potential for increasing strength, and in some cases, plastic characteristics. This suggests that changing the thickness of individual layers and their layout in multilayer structures makes possible regulation of the complex of characteristics of strength and plasticity in general.

In order to determine the conditions for the achievement of the better mechanical characteristics of multilayer structures, the flexure tests were accompanied with a series of experiments on the manufacture of samples consisting of three layers. The first layer (1)-Ti-6Al-4V alloy; the second layer (2)- $\mathrm{Ti}-6 \mathrm{Al}-4 \mathrm{~V}$-based composite with $5 \%$ strengthening particles; finally, the third layer (3)- Ti-6Al-4V-based composite with $10 \%$ strengthening particles. During the experiments, we tested samples that differed in three parameters: the type of particles in composites (TiB or $\mathrm{TiC}$ ), the mutual arrangement of the three above-mentioned layers relative to the flexure force (e.g., $1-2-3$ or $1-3-2$ ), and their individual thickness conserving unchanged the total (overall) thickness of the samples. We confirmed that all above-mentioned parameters sig- 

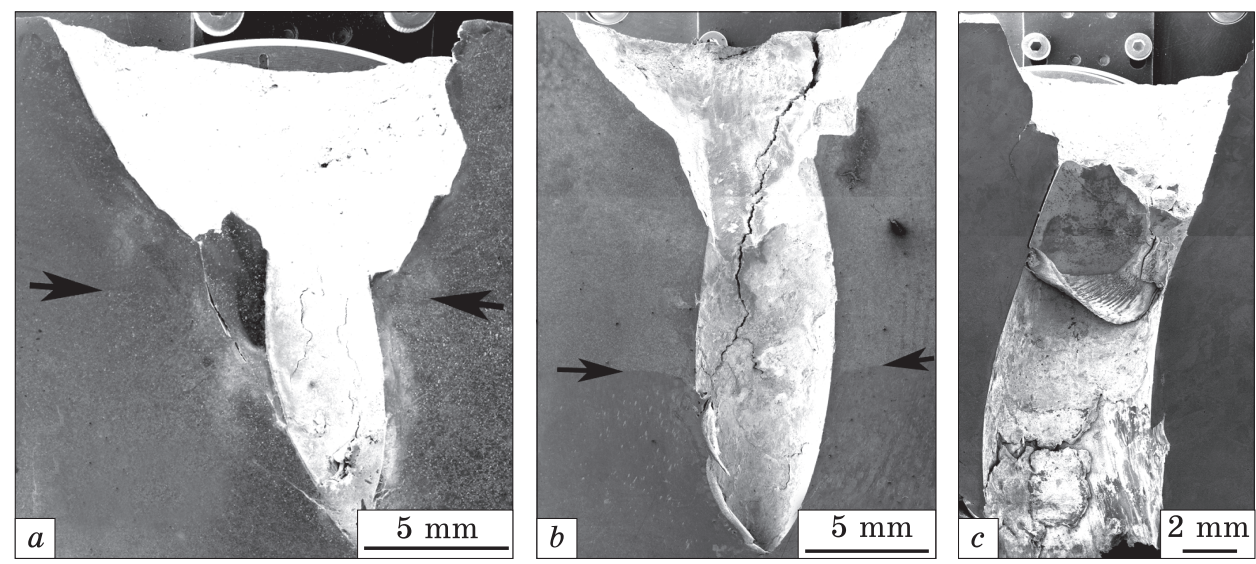

Fig. 13. Comparison of the cross-section of the areas where the third-type bullets (B32) hit into the experimental samples with two-composite layers on the top and an alloy layer on the bottom $(a, b)$ and an commercial plate of $\mathrm{Ti}-6 \mathrm{Al}-4 \mathrm{~V}$ alloy having uniform microstructure $(c)$. Arrows in the figures left and in the middle indicate the interphase boundary between the layers. The images are obtained via the SEM

nificantly affect the balance of strength and plasticity. When these parameters were changed, the flexure strength of the three-layer samples varied from $1100 \mathrm{MPa}$ to 2200-2300 $\mathrm{MPa}$, and the deformation varied from 6 to 24\% . A typical example of a change of the mechanical characteristics, depending on only one parameter (the mutual thickness of the layers), in the flexure tests is given in Fig. 11 for samples that contain some composite layers strengthened with TiC particles. These results allowed determining the parameters for obtaining 2-3 layer structures with promising characteristics for practical usage.

\subsubsection{Results of Ballistic Tests}

Obtained (via optimized powder process parameters) two-three-layer flat samples were tested for suitability for use as armour protection components. For comparison, the industrial (cast and hot deformed) plate of $\mathrm{Ti}-6 \mathrm{Al}-4 \mathrm{~V}$, with a thickness of $23 \mathrm{~mm}$ and a homogeneous microstructure was also tested at the same conditions. The image of the samples after the ballistic tests is depicted in Fig. 12. Materials consisting of two-three layers of different composition (including composites with different content of $\mathrm{TiC}$ or $\mathrm{TiB}$ particles and $\mathrm{Ti}-6 \mathrm{Al}-4 \mathrm{~V}$ alloy) exhibit high protective properties, which exceed the characteristics of the plate of a homogeneous $\mathrm{Ti}-6 \mathrm{Al}-4 \mathrm{~V}$ alloy with the same thickness, which Fig. 13 clearly demonstrates. Experimental two-three-layer samples withstood the impact of bullets of different types and calibre, including armour-piercing BZ bullets. At that, the depth of penetration of the armour-piercing bullet into the layered structures was 
about $18 \mathrm{~mm}$, while a uniform plate of $23 \mathrm{~mm}$ thick alloy was pierced through and through.

\section{Conclusions}

1. A detailed study of the stability of titanium T110 and VT6 alloys, obtained by the standard vacuum melting and hot-deformation technology, as well as metal-matrix $\mathrm{Ti}-6 \mathrm{Al}-4 \mathrm{~V}$-based composites hardened with solid particles of $\mathrm{TiC}$ and $\mathrm{TiV}$, versus the damage with different types of weapons and projectiles (bullets) in the certified laboratory conditions was performed.

2. Testing the plates (sheets) of titanium alloys obtained with conventional the cast and wrought technology, and subjected to various heat treatments for the formation of different types of microstructure, showed the undeniable advantage of the T110 alloy over the VT6 (Ti-6$\mathrm{Al}-4 \mathrm{~V})$. At the same time, the best resistance of the T110 alloy is revealed after a surface high-speed thermal treatment, which allows creating a graded state that combines a thermally strengthened surface with a ductile matrix.

3. The data obtained in the work allowed determining the impact ballistic resistance of the titanium alloys in the form of the dependence of the thickness of the plates (sheets) on the specific kinetic energy of the bullets. In addition, we ascertained how these characteristics depend on the types of used projectiles: bullets with 'soft' unhardened steel cores, bullets with highly hardened steel core, and bullets, in which the hardened core combines with an incendiary mix.

4. Based on previously obtained data on optimization the structure and mechanical characteristics of multilayer materials obtained by the blended elemental powders method, this approach was used to fabricate two- and three-layer Ti-6Al-4V (VT6) alloy-based experimental plates, in which the surface layers were composites strengthened with the TiC particles. Ballistic tests with the same bullets (used for tests obtained via the standard casting method of the same composition VT6 alloy) established an undeniable advantage of the layered material of the same thickness.

Acknowledgements. Parts of this work were supported by the $\mathrm{Na}$ tional Academy of Sciences of Ukraine within the framework of goaloriented scientific and technical program 'Research and Development on the Problems of Increasing State Defence and Security' (project IMФ$2017 / 1$ ) and project NATO G5030 of the program 'Science for Peace and Security'. Authors also acknowledge support within the collaboration agreement between the G.V. Kurdyumov Institute for Metal Physics of the N.A.S. of Ukraine and the Ivan Cherniakhovsky National Defence University of Ukraine. 


\section{REFERENCES}

1. G. Luetjering and J.C. Williams, Titanium (Berlin-Heidelberg: Springer: 2007). https://doi.org/10.1007/978-3-540-73036-1

2. U. Zwicker, Titan und Titanlegierungen (Berlin-Heidelberg: Springer: 1974) (in German). https://doi.org/10.1007/978-3-642-80587-5

3. J. Fanning, J. Mater. Eng. Perform., 14, Iss. 6: 686 (2005). https://doi.org/ $10.1361 / 105994905 \times 75457$

4. J.S. Montgomery and M.G.Y. Wells, JOM, 53, Iss. 4: 29 (2001). https://doi.org/ 10.1007/s11837-001-0144-2

5. C. Zheng, F. Wang, and X. Cheng, Int. J. Impact Eng., 85: 161 (2015). https:// doi.org/10.1016/j.ijimpeng.2015.06.017

6. G. Lutjering, Mater. Sci.Eng.A, 243, Iss. 1-2: 32 (1998). https://doi.org/10.1016/ S0921-5093(97)00778-8

7. P.E. Markovsky and S.L. Semiatin, J. Mater. Process. Technol., 210, Iss. 3: 518 (2010). https://doi.org/10.1016/j.jmatprotec.2009.10.015

8. P.E. Markovsky and S.L. Semiatin, Mater. Sci. Eng. A, 528, Iss. 7-8: 3079 (2011). https://doi.org/10.1016/j.msea.2010.12.002

9. P.E. Markovsky, Key Eng. Mater., 436: 185 (2010). https://doi.org/10.4028/ www.scientific.net/KEM.436.185

10. S.V. Akhonin, P.E. Markovsky, V.A. Berezos, O.O. Stasyuk, and A.Yu. Severin, Sovrem. Elektrometall., No. 1: 9 (2018) (in Russian). https://doi.org/10.15407/ sem2018.01.02

11. O.M. Ivasishin, S.V. Akhonin, D.G. Savvakin, V.A. Berezos, V.I. Bondarchuk, O.O. Stasyuk, and P.E. Markovsky, Usp. Fiz. Met., 19, Iss. 3: 309 (2018). https://doi.org/10.15407/ufm.19.03.309

12. O.M. Ivasishin, D.G. Savvakin, and M.M. Gumenyak, Metallofiz. Noveishie Tekhnol., 33, Iss. 7: 899 (2011).

13. O.M. Ivasishin, D.G. Savvakin, K.A. Bondareva, V.S. Moxson, and V.A. Duz, Nauka Innov., 1, No. 2: 45 (2005). https://doi.org/10.15407/scin1.02.044

14. O.M. Ivasishin and P.E. Markovsky, JOM, 48, Iss. 7: 48 (1996). https://doi. org/10.1007/BF03222998

15. P.E. Markovsky and M. Ikeda, Mater. Trans., 46, No. 7: 1515 (2005).

16. O.M. Ivasishin, P.E. Markovsky, Yu.V. Matviychuk, S.L. Semiatin, C.H. Ward, and S. Fox, J.Alloys Compd., 457, Iss. 1-2: (296) 2008. https://doi.org/10.1016/j. jallcom.2007.03.070

17. T.L. Jones, Ballistic Performance of Titanium Alloys: Ti-6Al-4V Versus Russian Titanium (Army Research Laboratory Report ARL-CR-0533: 2004).

18. J. Fanning, Proc. 11th World Conference on Titanium) (June 3-7, 2007, Kyoto, Japan) (Kyoto: The Japan Institute of Metals: 2007), p. 487.

19. O.M. Ivasishin, P.E. Markovsky, D.G. Savvakin, V.I. Bondarchuk, A.A. Stasyuk, and S.V. Prikhodko, Sovrem Elektrometall., No. 3: 52 (2018). https://doi. org $/ 10.15407 /$ sem2018.03.08

20. D.G. Savvakin, S.V. Prikhodko, M.V. Matviychuk, and O.M. Ivasishin, Presentation at International Titanium Association ITA-2017 Conference (8-11 October 2017, Miami, USA).

21. T.M. Godfrey, P.S. Goodwin, and C.M. Ward-Close, Adv. Eng. Mat., 2, Iss. 3: 85 (2000). https://doi.org/10.1002/(SICI)1527-2648(200003)2:3<85::AIDADEM85>3.0.CO;2-U

22. S.V. Prikhodko, D.G. Savvakin, P.E. Markovsky, O.O. Stasiuk, M. Norouzi Rad, C. Choi, and O. M. Ivasishin, Microsc. Microanal, 24, Suppl. 1: 2218 (2018). https://doi.org/10.1017/S1431927618011571 
23. S. Prikhodko, D.G. Savvakin, O.O. Stasyuk, P.E. Markovsky, and O.M. Ivasishin, Material Science Forum, 941: 1384 (2018). https://doi.org/10.4028/ www.scientific.net/MSF.941.1384

24. O.M. Ivasishin, P.E. Markovsky, D.G. Savvakin, O.O. Stasyuk, S.D. Sitzman, M. Norouzi Rad, and S. Prikhodko, J. Mater. Process. Technol., 269: 172 (2019). https://doi.org/10.1016/j.jmatprotec.2019.02.006

25. P.E. Markovsky, Material Science Forum, 941: 839 (2018). https://doi.org/ 10.4028/www.scientific.net/MSF.941.839

Received February 26, 2019;

in final version, April 18, 2019

О.М. Івасишин ${ }^{1}$, П.Є. Марковський ${ }^{1}$, Д.Г. Саввакін ${ }^{1}$,

O.O. Стасюк ${ }^{1}$, В.A. Голуб ${ }^{2}$, В.I. Мірненко ${ }^{2}$,

С.Г. Сєдов ${ }^{2}$, В.А. Курбан ${ }^{2}$, С.Л. Антонюк ${ }^{3}$

${ }^{1}$ Інститут металофізики ім. Г.В. Курдюмова НАН України, бульв. Академіка Вернадського, 36; 03142 Київ, Україна

${ }^{2}$ Національний університет оборони України ім. Івана Черняховського, Повітрофлотський проспект, 28; 02093 Київ, Україна

${ }^{3}$ ДП «АНТОНОВ», вул. Туполєва, 1; 03062 Київ, Україна

МІКРОСТРУКТУРА ТА ВЛАСТИВОСТІ МАТЕРІАЛІВ

НА ОСНОВІ ТИТАНУ, ПЕРСПЕКТИВНИХ

ДЛЯ ПРОТИБАЛІСТИЧНОГО ЗАХИСТУ

Титанові матеріали, які поєднують високу міцність і твердість поверхні при достатніх пластичних характеристиках основного металу, є перспективними для використання в різних галузях техніки, зокрема, в якості бронеелементів у військово-промисловому комплексі. Одержати вищевказану комбінацію властивостей можливо, створюючи матеріали, які складаються з декількох шарів, що відрізняються за своїми фізико-механічними характеристиками. В роботі досліджено особливості мікроструктури, механічних характеристик і балістичної стійкости таких матеріалів, створених за двома підходами. Першим є стандартний підхід, що поєднує виготовлення та гарячу деформацію зливків з наступним поверхневим швидкісним термічним обробленням сплавів BT6 (Ti-6Al-4V) та T110, що створює в них градієнтні структурні стани, зі зміною механічних характеристик по глибині матеріалу. Іншим є порошковий підхід для створення структур, які поєднують шари сплаву $\mathrm{Ti}-6 \mathrm{Al}-4 \mathrm{~V}$ і композитів на його основі, зміцнених частинками ТiВ або ТіС. Проведено балістичні випробування одержаних матеріалів різними типами набоїв, що відрізняються кінетичною енергією, твердістю осердя та наявністю запалювальної суміші; досліджено особливості проникнення уражальних елементів, залежно від структурного стану матеріалу. Доведено, що матеріали 3 градієнтною та шаруватою структурами мають незаперечні переваги за захисними протибалістичними характеристиками, порівняно з однорідними титановими стопами тієї ж товщини.

Ключові слова: титанові сплави, шарувата та градієнтна мікроструктури, механічні характеристики, балістичні випробування. 
О.М. Ивасишин ${ }^{1}$, П.Е. Марковский ${ }^{1}$, Д.Г. Саввакин ${ }^{1}$, А.А. Стасюк ${ }^{1}$, В.А. Голуб ${ }^{2}$ В.И. Мирненко ${ }^{2}$, С.Г. Седов ${ }^{2}$, В.А. Курбан ${ }^{2}$, С.Л. Антонюк ${ }^{3}$

${ }^{1}$ Институт металлофизики им. Г.В. Курдюмова НАН Украины, бульв. Академика Вернадского, 36; 03142 Киев, Украина

${ }^{2}$ Национальный университет обороны Украины им. Ивана Черняховского, Воздухофлотский проспект, 28; 02093 Киев, Украина

${ }^{3}$ ГП «АНТОНОВ», ул. Туполева, 1; 03062 Киев, Украина

\section{МИКРОСТРУКТУРА И СВОЙСТВА МАТЕРИАЛОВ НА ОСНОВЕ ТИТАНА, ПЕРСПЕКТИВНЫХ ДЛЯ ПРОТИВОБАЛЛИСТИЧЕСКОЙ ЗАЩИТЫ}

Титановые материалы, которые совмещают высокую прочность и твёрдость поверхности при достаточных пластических характеристиках основного металла, являются перспективными для использования в различных областях техники, в частности, как бронеэлементы в военно-промышленном комплексе. Достичь такой комбинации свойств возможно, создавая материалы, состоящие из нескольких слоёв, которые отличаются по своим физико-механическим характеристикам. В работе исследованы особенности микроструктуры и механических характеристик таких материалов, созданных двумя путями. Первым является стандартный металлургический подход с последующей поверхностной скоростной термической обработкой поверхности сплавов ВT6 (Ti-6Al-4V) и T110, который формирует в них градиентные структурные состояния, с изменением механических свойств по глубине материала. Второй - порошковый подход для создания структур, объединяющих слои сплава $\mathrm{Ti}-6 \mathrm{Al}-4 \mathrm{~V}$ и композитов на его основе, упрочнённых частицами $\mathrm{TiB}$ или ТіC. Проведены баллистические испытания полученных материалов разными типами поражающих элементов, которые отличаются кинетической энергией и твёрдостью сердечника; исследованы особенности проникновения поражающих элементов в структуры разных типов. Доказано, что материалы с градиентной и слоистой структурами имеют преимущество по защитным противобаллистическим характеристикам в сравнении с однородными титановыми сплавами той же толщины.

Ключевые слова: титановые сплавы, слоистая и градиентная микроструктуры, механические характеристики, баллистические испытания. 